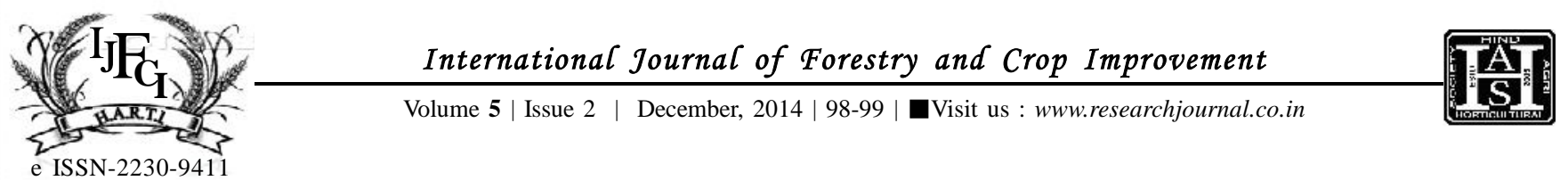

Research Note

DOI: $10.15740 / \mathrm{HAS} / \mathrm{IJFCI} / 5.2 / 98-99$

\title{
Varietal response of Bela on productivity and profitability under climate change
}

\begin{abstract}
Amar Singh, R.A. SingH and V.K. KanAuJia
ABSTRACT : The FLD was laidout in cluster on eleven farmers fields during Zaid season of 2010 at Kannauj district. The pilot area situated in the catchments area of river Kali, having loam soil with low fertility status. The main objective of the study was to pluck higher flowers yield, maximum net return and desired recovery of concrete. The secondary objective was to increase the living standard of farm families reeling below the poverty line. The flowers yield of cv. MOGRA SINGLE of Bela was recorded by $76.80 \mathrm{q} / \mathrm{ha}$, which was higher by a margin of $16.00 \mathrm{q} / \mathrm{ha}$ or 26.31 per cent than the familiour indigenous cultivar ( $60.80 \mathrm{q} / \mathrm{ha}$ ). The maximum gross return of Rs. 307200/ha, net return of Rs. $249540 /$ ha and BCR of 1:5.32 were found with plucking of marketable flowers from raising of cv. MOGRA SINGLE than the gross return of Rs. 243200/ha, net return of Rs. 191000/ha and BCR of 1:4.65 computed under indigenous variety. Therefore, cv. MOGRA SINGLE can be raised on riverine soil for plucking of faney flowers and improving livelihood security of small and marginal farmers.
\end{abstract}

KEY WORDS : Aromatic plants, Concrete, Fancy flowers yield, Mogra Single, Riverine soil

How to cite this Article : Singh, Amar, Singh, R.A. and Kanaujia, V.K. (2014). Varietal response of Bela on productivity and profitability under climate change. Internat. J. Forestry \& Crop Improv., 5 (2) : 98-99.

Article Chronical : Received : 13.10.2014; Accepted : 30.11.2014

MEMBERS OF RESEARCH FORUM

Address of the Correspondence :

R.A. SINGH, C.S. Azad university of Agriculture and Technology, KANPUR (U.P.) INDIA

Email: rasinghcsau@gmail.com

Address of the Coopted Authors :

AMAR SINGH AND V.K. KANAUJIA, Krishi Vigyan Kendra, Anogi,

Jalalabad, KANNAUJ (U.P.) INDIA 